E3S Web of Conferences 1, 41001 (2013)

DOI: $10.1051 / \mathrm{e} 3$ sconf/ 20130141001

(C) Owned by the authors, published by EDP Sciences, 2014

\title{
A Survey of Heavy Metals content of Soil and plants As Affected by Long-Term Application of Sewage Water. A Case Study
}

\author{
E. M. Abd El Lateef ${ }^{1}$, J. E. Hall ${ }^{2}$, S. R. Smith ${ }^{3}$, B. A. Bakry ${ }^{1}$ and T. A. Elewa ${ }^{1}$ \\ ${ }^{1}$ Field Crop Research Department, Agricultural Division, National Research Centre, Cairo, Egypt, 12611 \\ ezzlatnre@yahoo.com \\ ${ }^{2}$ Independent Sludge and Water Expert, UK sludgehall@hotmail.com \\ ${ }^{3}$ Imperial College, Dept of Civil and Environmental Engineering, London, SW7 2BU, UK
}

\begin{abstract}
As part of a four year study evaluating the practicability and value of sewage sludge use in Egypt, soil and plant surveys were carried out on a citrus plantation, irrigated with Cairo sewage since the 1920s, in order to evaluate the long-term accumulation of trace elements and heavy metals and their bioavailability. While total and DTPA soil concentrations correlated well, no relationship could be found between soil and plant tissue concentrations, despite elevated levels of heavy metals in the soil. Study of long-term contamination of soil with potentially toxic elements (PTEs) has not demonstrated a potential risk to crop quality and yield or human health from the slow accumulation of PTEs in sludge-treated agricultural soil. PTE concentrations in plant tissues remained low and within normal ranges despite significant increases in soil content after long-term irrigation with sewage effluent. Concentrations of PTEs in plant tissues were not related to total or DTPA extractable metals in contaminated soil. DTPA may not be a sufficiently reliable indicator of actual phytoavailability of trace elements in sludge-treated soil, although it is accepted that DTPA is widely used in nutrient diagnosis assessment. These data provide assurance about the minimal risk to the environment from trace elements and PTEs in sludge-treated agricultural soil, but a more detailed dietary analysis of $\mathrm{Cd}$ intakes under Egyptian conditions is recommended, following the approaches adopted in the UK and US for setting Cd soil limits or loading rates for this element.
\end{abstract}

Keywords: DTPA extraction, citrus, $\mathrm{Cu}, \mathrm{Cd}$, leaf concentration, soil concentration, toxicity, $\mathrm{Zn}$

\section{Introduction}

Cairo is now served by six large wastewater treatment works which produce significant quantities of sludge. The preferred option is to use this in agriculture, particularly on reclaimed desert land which is inherently deficient in organic matter, nutrients and trace elements. However, there are concerns about the long-term accumulation and potential effects of heavy metals, and as and as part of the Cairo Sludge Disposal Study, a number of field trials and surveys have been carried out.

The Gabal El Asfar Farm is a fruit plantation on reclaimed desert land north of Cairo. It has been irrigated with sewage for over 90 years and there are concerns about the contamination of the site by potentially toxic heavy metals. The site provides a possible model of the potential long-term effects of heavy metals on crops for sewage sludge-treated soils in Egypt.

\section{Materials and Methods}

The heavy metal contents of citrus leaves and fruit (orange and mandarin) and total and DTPA extractable concentrations in soils were measured in samples collected from different areas of Gabal El Asfar Farm during two surveys of the site in 1997.

\section{Results and Discussion}

Total and DTPA concentrations of heavy metals in the surveyed soils showed significant enrichment by longterm irrigation with sewage effluent. For example, the maximum total concentrations of $\mathrm{Zn}$ and $\mathrm{Cu}$ were 530 and $366 \mathrm{mg} \mathrm{kg}^{-1}$, respectively, representing a potential risk to crop yields (Table 1). The maximum $\mathrm{Cd}$ concentration detected was $9 \mathrm{mg} \mathrm{kg}^{-1}$ and $\mathrm{Cd}$ may be a potential risk to the human food chain from uptake into staple crops grown at the farm. The concentrations of DTPA extractable metals were also increased by sewage 
(a) DTPA $\vee$ Total Zn

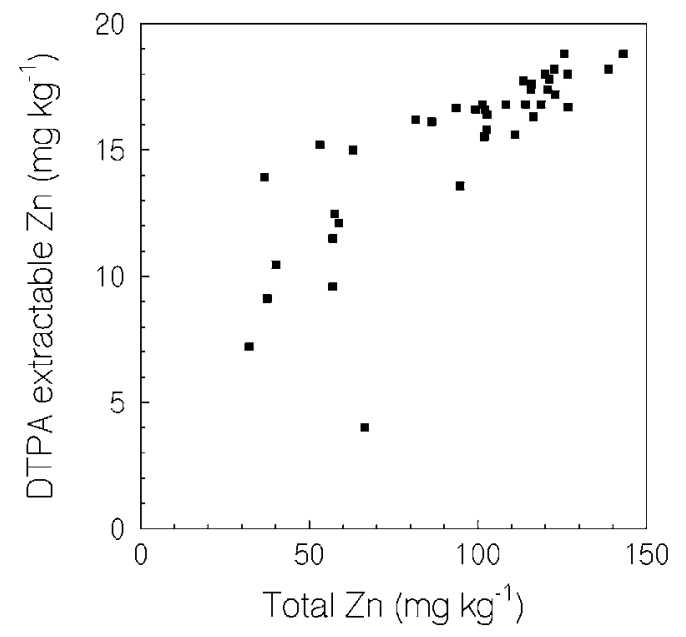

Fig. 1a. Relationships between total and extractable $\mathrm{Zn}$ in soil at Gabal El Asfar Farm (Survey 2)

Table 1. Total heavy metal content $\left(\mathrm{mg} \mathrm{kg}^{-1}\right)$ of soil at Gabal El Asfar Farm

\begin{tabular}{llll} 
Element & \multicolumn{1}{c}{ Minimum } & \multicolumn{1}{c}{$\begin{array}{c}\text { Maximum } 1 \\
\text { Maximum }\end{array}$} & \multicolumn{1}{c}{ Mean } \\
$\mathrm{Zn}$ & 180 & 530 & 331 \\
$\mathrm{Cu}$ & 50 & 117 & 84 \\
$\mathrm{Ni}$ & 1 & 51 & 22 \\
$\mathrm{Cd}$ & 1 & 9 & 3 \\
$\mathrm{~Pb}$ & 5 & 70 & 23 \\
$\mathrm{Cr}$ & 80 & 230 & 154 \\
\hline & \multicolumn{3}{c}{ Survey 2 } \\
$\mathrm{Zn}$ & 32 & 143 & 95 \\
$\mathrm{Cu}$ & 7 & 366 & 67 \\
$\mathrm{Ni}$ & 10 & 92 & 45 \\
$\mathrm{Cd}$ & 0.2 & 4.6 & 1.6 \\
$\mathrm{~Pb}$ & 16 & 290 & 70 \\
$\mathrm{Cr}$ & 2 & 376 & 89 \\
\hline
\end{tabular}

application and were significantly correlated $(\mathrm{P}<0.001)$ with the total contents of $\mathrm{Zn}(\mathrm{r}=0.81), \mathrm{Cu}$ $(\mathrm{r}=0.89), \mathrm{Ni}(\mathrm{r}=0.88), \mathrm{Cd}(\mathrm{r}=0.73)$ and $\mathrm{Pb} \quad(\mathrm{r}=0.62)$ (Figure 1a).

However, crop analysis showed no relationships were apparent between tissue content (Table 2) and the corresponding total and DTPA extractable concentrations in soil for $\mathrm{b}$ ). Leaf $\mathrm{Zn}$ and $\mathrm{Cu}$ concentrations were in the low (16-24 and 3.6-4.9 mg kg-1 , respectively) to optimum (25-100 and 5-16 $\mathrm{mg} \mathrm{kg}^{-1}$, respectively) ranges for citrus. The other heavy metals were within normal ranges.

Whilst DTPA is widely used in nutrient diagnosis assessment, it has not provided a reliable indication of the bioavailability of potentially toxic elements to citrus in reclaimed desert soil. This study has contributed to a broader understanding of the behaviour of heavy metals (b) Leaf $\vee$ Extractable Zn

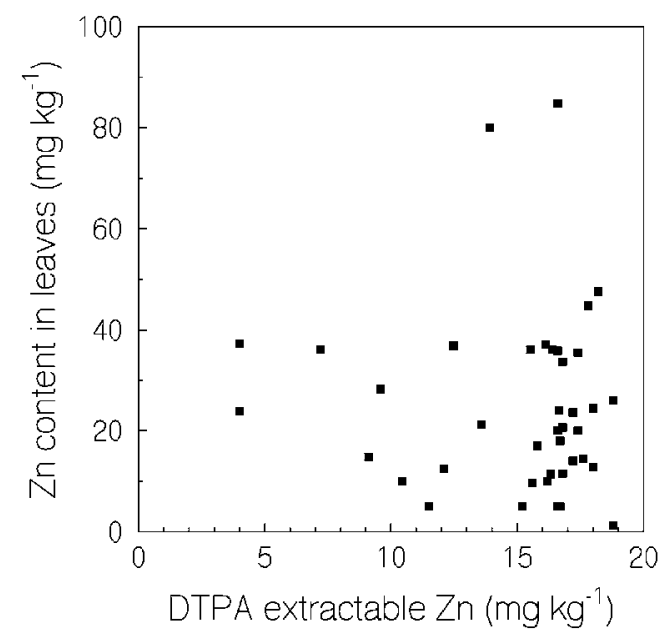

Fig. 1b. Relationships between extractable $\mathrm{Zn}$ in soil and $\mathrm{Zn}$ content of citrus leaves at Gabal El Asfar Farm (Survey 2)

Table 2. Correlation coefficients (r) of relationships between metal concentrations in soil and citrus at Gabal El Asfar Farm

\begin{tabular}{lllll} 
& \multicolumn{2}{c}{ Fruit } & \multicolumn{2}{c}{ Leaves } \\
$\mathrm{Cd}$ & $0.39 \mathrm{~ns}$ & $0.35 \mathrm{~ns}$ & $0.35 \mathrm{~ns}$ & $0.47 \mathrm{~ns}$ \\
$\mathrm{~Pb}$ & $0.24 \mathrm{~ns}$ & $-0.24 \mathrm{~ns}$ & $-0.10 \mathrm{~ns}$ & $0.04 \mathrm{~ns}$ \\
$\mathrm{Cr}$ & $0.09 \mathrm{~ns}$ & $0.01 \mathrm{~ns}$ & $0.01 \mathrm{~ns}$ & $-0.05 \mathrm{~ns}$ \\
$\mathrm{Zn}$ & $-0.11 \mathrm{~ns}$ & $0.03 \mathrm{~ns}$ & $-0.01 \mathrm{~ns}$ & $0.05 \mathrm{~ns}$ \\
$\mathrm{Cu}$ & $0.27 \mathrm{~ns}$ & $-0.03 \mathrm{~ns}$ & $0.36 \mathrm{~ns}$ & $0.24 \mathrm{~ns}$ \\
$\mathrm{Ni}$ & $0.06 \mathrm{~ns}$ & $-0.35 \mathrm{~ns}$ & $0.38 \mathrm{~ns}$ & $0.18 \mathrm{~ns}$ \\
\hline
\end{tabular}

ns: not significant at $\mathrm{P}=0.05$

in reclaimed sandy and calcareous desert soil which is the principal 'market' for sludge in Egypt. As part of the Cairo Sludge Disposal Study (Smith et al., 1995: 1999), funded through the European Investment Bank, this has contributed to the development of Egyptian standards for sludge use in agriculture (Decree 214, 1997). Cairo Sludge Disposal Study (Smith et al., 1995: 1999), funded through the European Investment Bank, this has contributed to the development of Egyptian standards for sludge use in agriculture (Decree 214, 1997).

\section{References}

Decree 2141997 Concerning Processing and Safe Use of Sludge. Min. of Housing, Utilities and Urban Com., Egypt.

Smith, S R, Abd El Lateef E M, Hall J E, and Rasheed A A 1995 The Agricultural Use of Sewage Sludge in Warm Climates, with Special Reference to Egypt. WRc Medmenham, UK.

Smith, S R, Abd El Lateef E M, Hall J E, and Rasheed A A 1999 Scientific Justification for Agricultural Use of Sewage Sludge in Egypt. WRc Medmenham, UK. 